\title{
PROBLEMS AND OPPORTUNITIES IN THE HOSPITALITY INDUSTRY IN A MASKED AND RUBBER-GLOVED WORLD
}

\author{
Sotiris Folinas, Marie-Noëlle Duquenne, and Theodore Metaxas
}

\begin{abstract}
As the global tourism industry is under sway of the novel Coronavirus, and the world still remains with a limited medical capacity to threat the pandemic, with no vaccine and with its only weapon of precautionary measures, masks, gloves and lockdown, a part of hospitality industry develops new stratagems and applies new tactics to survive the upcoming financial debacle. The almost worldwide lockdown, the brutal impact of mass cancelations caused by the virus spread, and the people's significantly reduced willingness to travel produce major upheavals in the tourism economy. The purpose of this study is to systematize the problems and opportunities in the hospitality industry in a pandemic. For this study there has been applied the secondary research methodology with several pieces of literature such as scientific journal articles, preprint papers, government documents, data from global organizations and mass media data etc., but no primary research was conducted. As the phenomenon is still ongoing, there is not yet the significant number of published papers about the opportunities in the hospitality sector. The main findings of the present study are demonstrating that, although this situation makes tourism highly vulnerable, the sector is also in a unique position to contribute to broader and just recovery plans and actions. Significant conclusions are the vulnerability of the travel sector and travel restrictions' effects on hospitality industry, the appearance of a new form of hotel clients - 'quarantine guests', and the need of new survival strategies on hotel industry based on virtualization and domestication.
\end{abstract}

Keywords: coronavirus, COVID-19, problems, opportunities, hospitality industry, global tourism, economic impact

JEL Classification: Z32 


\section{Authors:}

Sotiris Folinas*

Department of Planning and Regional Development, University of Thessaly, Volos, Greece E-mail: sfolinas@uth.gr; *Corresponding author https://orcid.org/0000-0002-1791-0305

\section{Marie-Noëlle Duquenne}

Department of Planning and Regional Development, University of Thessaly, Volos, Greece E-mail:mdyken@uth.gr https://orcid.org/0000-0002-3189-5658

\section{Theodore Metaxas}

Department of Economics, University of Thessaly, Volos, Greece E-mail: metaxas@econ.uth.gr https://orcid.org/0000-0002-6781-1401

Citation: Folinas, S., Duquenne, M.N., \& Metaxas, T. (2020). Problems and Opportunities in the Hospitality Industry in a Masked and Rubber-Gloved World. Virtual Economics, 3(3), 7-24. https://doi.org/10.34021/ve.2020.03.03(1)

Received: March 9, 2020. Revised: June 3, 2020. Accepted: July 6, 2020.

(C) Author(s) 2020. Licensed under the Creative Commons License - Attribution 4.0 International (CC BY 4.0) 


\section{Introduction}

The World Health Organization (WHO) announced in early January 2020 a novel coronavirus to be the cause of pneumonia cases whose cause was unclear in PRC. The infection came to be known as a coronavirus disease (COVID-19) caused by severe acute respiratory syndrome coronavirus 2 (SARS-CoV-2) (Correa-Martínez et al., 2020). As coronavirus spread around the world, Europe shortly became the cynosure of the pandemic, which has since been overtaken by the United States (Wen et al., 2020). The pandemic's spread threatens to a great extent the hospitality sector (Yang et al., 2020) given its reliance on human mobility (Domínguez-Mujica et al., 2011; Lamsfus et al., 2015). The consequences of the novel coronavirus for the economy are the most disastrous in comparison with any other crisis in the recent history (Gretzel et al., 2020; Hall et al., 2020). The response to COVID-19-related crisis events provides insights into opportunities to challenge and make adjustments to the contemporaneous global economic conditions (Prideaux, 2020). In the entire human history, emergencies and disasters have been essential to societies' process and development (Mishkin, 1992). So, in particular, diseases and pandemics have diachronically helped advance health-care systems, wars and conflicts have fuelled technological innovations and the global financial crisis helped advance tech companies such as 'AirBnB' (Oskam \& Boswijk, 2016; Aznar et al., 2017) or 'Uber' (Kim et al., 2018). Therefore, the COVID-19 pandemic, without doubt, will not be an exception; entrepreneurs and tourism practitioners can be expected to rise to the challenge.

\section{Research Methodology}

To meet the objective this study follows secondary research methodology approach. As the phenomenon of novel coronavirus spread is still in progress, there are not yet many published articles demonstrating a full range of both problems and opportunities in hospitality sector in the time of COVID-19 outbreak. Criteria for selecting data that come from various sources, such as scientific journals, preprints, governmental and official authorities' announcements, online mass media and international organizations intelligence are the validity of the source, authors' expertise and the significance of information.

\section{The Effects of the Pandemic on the Global Economy}

As the novel coronavirus declared a pandemic outbreak, stocks entered the bear market in January 2020, but that decline did not last long and losses were quickly compensated. January's and February's declines were, generally, in the Asian markets, especially in China. Despite the strict measures taken into account in China, it was impossible to prevent the global spread of virus, so the stock markets at the global level collapsed. The stock markets further declined when the World Health Organization announced coronavirus as a global pandemic on January 30, 2020, and a public health emergency is of international concern (Kumar, 2020). From 1 January to 1 April, MSCI World Index -25\%, MSCI Emerging Markets Index $-26 \%$, MSCI Europe Index -27\% and G7 Index -25\% depreciated (Şenol \& Zeren, 2020). In early March of 2020, the brutal drawdown in global financial markets probably indicates that the global economy is on a path to recession (Carlsson-Szlezak et al., 2020). The pandemic has also led 
to increases in stock-price volatility, decreases in nominal interest rates, and leads to contractions of real economic activity, as reflected in the real GDP (Barro et al., 2020).

This economic downturn does not seem to be avoided, as even the crash of oil prices clearly shows it (Albulescu, 2020). Several countries are facing a slowdown because of the integrated international supply chain and prices for oil, metals or other materials have also fallen on expectations of lower demand. Even such sectors as technology and the global fashion industry feel the impacts (Maffioli, 2020). The negative effects of COVID-19 have also been observed in e-commerce sector and business travel (Hasanat et al., 2020).

Furthermore, according to Fernandes (2020), comparisons of the COVID-19 pandemic with previous global crises, like the 2008 financial crisis, are not possible, because now the planet is facing a number of new challenges, which prevent simple comparisons with the past, such as: a global spread of the phenomenon, the fact that it does not focus on low/middle income countries, the fact that the word is much more integrated, interest rates are not in historical lows, the fact that the current crisis is generating spillover effects throughout supply chains, and simultaneous destruction of demand and supply.
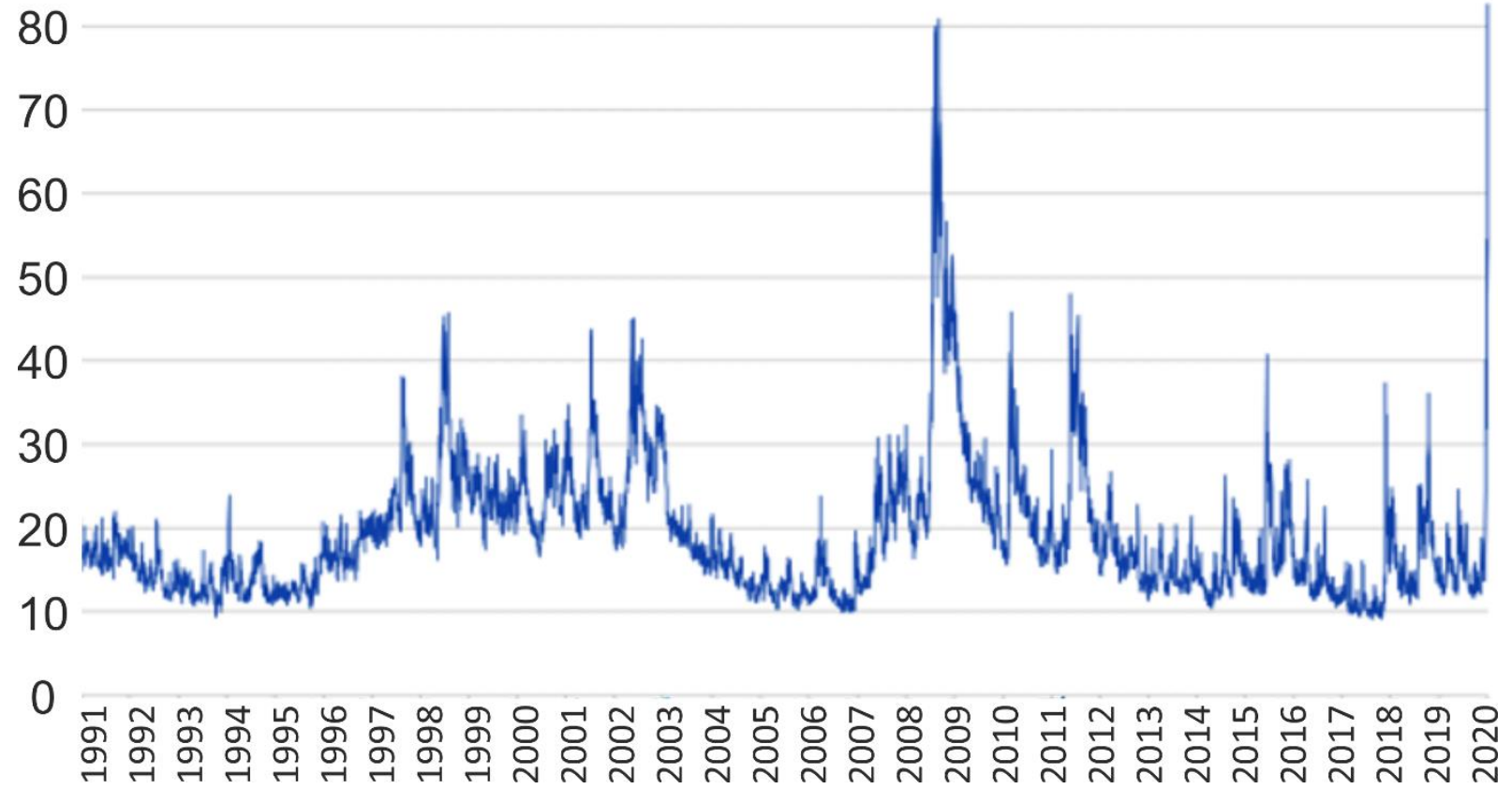

Figure 1. Implied Volatility Given by the VIX Index for the $16^{\text {th }}$ March Last Thirty Years (19912020)

Source: Cboe (2020).

The implied volatility of equity markets is often used as an indicator of how risky the current environment is, and how uncertain the future is. For instance, the VIX index is commonly referred to as the "fear index." It is based on the traded prices of options on the S\&P 500 index 
and represents the market expectation of stock volatility over the next 30 days (Fernandes, 2020). As Figure 1 shows, the VIX long-term average is approximately 20 per cent. However, it can clearly be seen that it rose significantly in the aftermath of the 2007/2008 financial crisis, thus, reflecting the investors' uncertainty about the future. Today, it is actually above those levels. All previous crises have been triggered by different events such as program trading collapse (Bossomaier et al., 2018), sovereign debt crisis (Lane, 2012; Arghyrou \& Kontonikas, 2012; Beirne \& Fratzscher, 2013), banking crisis (Englund, 1999; Chava \& Purnanandam, 2012), LTCM default (Jorion, 2000; Kabir \& Hassan, 2005; Dungey et al., 2006), Dot-Com bubble (Goodnight \& Green, 2010), political events, wars, etc., but the difference is that, in all those cases, central banks had at their disposal tools to prevent further damages. None of the previous examples was in the periods where the starting point of interest rates was so low, and, in some cases, negative. This could raise concern in the markets that there is little room for an effective policy response (Fernandes, 2020).

All these considered, it may be said that COVID-19 triggered a deep crisis in almost all the economies of the planet, and it is set to result in, perhaps, the worst recession since the 1920 Great Depression. Mobility and spending reduced drastically at the global level, and experts predict a slow economic recovery.

\subsection{Consequences of the Novel Coronavirus for the Global Tourism Industry}

A rapid spread of the novel coronavirus (2019-nCoV) since the first case that occurred in December 2019 in Wuhan, Mainland China (Ayittei et al., 2020; Hoque et al., 2020), led to a significant reduction in almost all global tourism (Folinas\& Metaxas, 2020; Estrada et al., 2020). With a lack of proper vaccines against the coronavirus and a limited medical capacity to treat the disease (Gössling et al., 2020), the planet seems to face an economic shock by declining export and tourism revenue in a large scale due to restricted export policies and travel bans. Tourism, the world's largest service sector industry (Lew, 2011; Metaxas \&Folinas, 2016), has been badly battered, as summer vacations seem to be off the table this year. Covid19 has led to some changes in the touristic consumer behaviors and also has generated risk, uncertainty and fear (Aydın \& Doğan, 2020). The travel and tourism industry came to a complete halt (Kumar, 2020), and the spread of the novel coronavirus demonstrates once again the tourism sector vulnerability to various types of crises, such as epidemics, terror, natural disasters, economic or political crises (Yozcu \& Cetin, 2019). In the opinion of Chang et al. (2020), the coronavirus has changed the world forever in every imaginable respect and has impacted heavily on the worldwide travel-tourism demand and the hospitality industry, one of the world's largest employers. Correspondingly, the world is now experiencing a temporary de-globalization, and by virtue of the heavy travel restrictions and the suspension of international travel, geographical barriers between places have re-emerged, relative distances have increased and remote places have again become truly remote (Niewiadomski, 2020). 


\subsection{The Demolition of the Global Air Travel Industry by the Coronavirus}

Several researchers agree that air connectivity is one of the outstanding factors for the tourism development in the global level (Ivy et al., 1995; Bannò \& Redondi, 2014). In addition, the connectivity brought by air transport is indispensable for the conveyance of people and goods, especially in places where surface transport networks are underdeveloped (Eric et al., 2020). Regarding the significance of air connectivity to tourism development, Van Houts (1984) argues that while mass tourism was possible by other means of transport, the great step forward was achieved by developments in commercial aviation. In other words, international approachability by air is required for developing any tourism destination and for integrating into the worldwide economy. More than fifty percent of all tourists arrive to their destinations by air and with their spending contribute to a 285 million jobs in global air transportation industry (Eric et al., 2020). As the worldwide economy is becoming more and more intertwined, the aviation industry is one of the fastest transportation sectors. Commercial airlines transported more than 4.5 billion passengers in 2019 and were expected to generate more than 580 billion U.S. dollars in global revenue in 2020. Air transportation also plays a significant role in tourism, contributing to economic growth, especially in developing countries. The number of global tourist arrivals escalated from 1.32 billion in 2017 to 1.4 billion in 2018; more than a half of tourists chose to reach their destination by air (Statista, 2020).

The mobility trend at the global level has been rising over the last ten years at a pace that is faster than the global world population growth (Recchi et al., 2019). However, air traffic flows have been shaped at the regional and national scale by shocks due to economic crises, terrorism or political instability (Gabrielli et al., 2019). In addition, the aviation industry has shown strong dependency on the past pandemic outbreaks, such as 2003 SARS or 2015 MERS (lacus et al., 2020), with effects that had repercussions at the regional and international scale. Since the coronavirus global outbreak, the air industry is undergoing the worst crisis in its history. The impact of this new crisis is more serious than the 9/11 terrorist attacks, the 2008 financial crash and virtually every other history-altering event of the jet age combined (Business Insider, 2020a).

As reported by the IBIS World market research, during the coronavirus crisis, the airline revenues lose about $\$ 1.6$ billion per day, while the aviation industry is typically worth around $\$ 825$ billion per year in the worldwide economy (Condé Nast Traveler, 2020). While landed the air industry cannot generate cash, cannot repay debts and cannot remunerate its own equity (European Investment Bank, 2020). Despite the $\$ 58$ billion bailout that the U.S. President signed for the aviation industry, CAPA Centre for Aviation alerts that the majority of global airlines are being threatened with bankruptcy due to the current pandemic (Business Insider, 2020b).

Since early February 2020, fifty-nine airline companies have limited or suspended flights to mainland China, and several other countries such as the United States, Italy, Russia and Australia, have imposed travel restrictions, issued by governments (Chinazzi et al., 2020). In the middle of April 2020, the region with the most drastic air traffic reduction globally was the 
Persian Gulf. Skies are usually congested with wide-body planes serving the three major hub airports there, which then connect to Europe, Asia, and Australia. In recent weeks, Emirates and Etihad have grounded all aircraft, except for a few repatriation flights departing the United Arab Emirates. Qatar continues to fly passengers, while some cargo plans also operate. According to WorldAware (2020), the result is an almost-empty airspace, with fewer than fifty airplanes in the skies at any one time, that is, around 300 aircraft fewer compared with the previous year (Condé Nast Traveler, 2020).

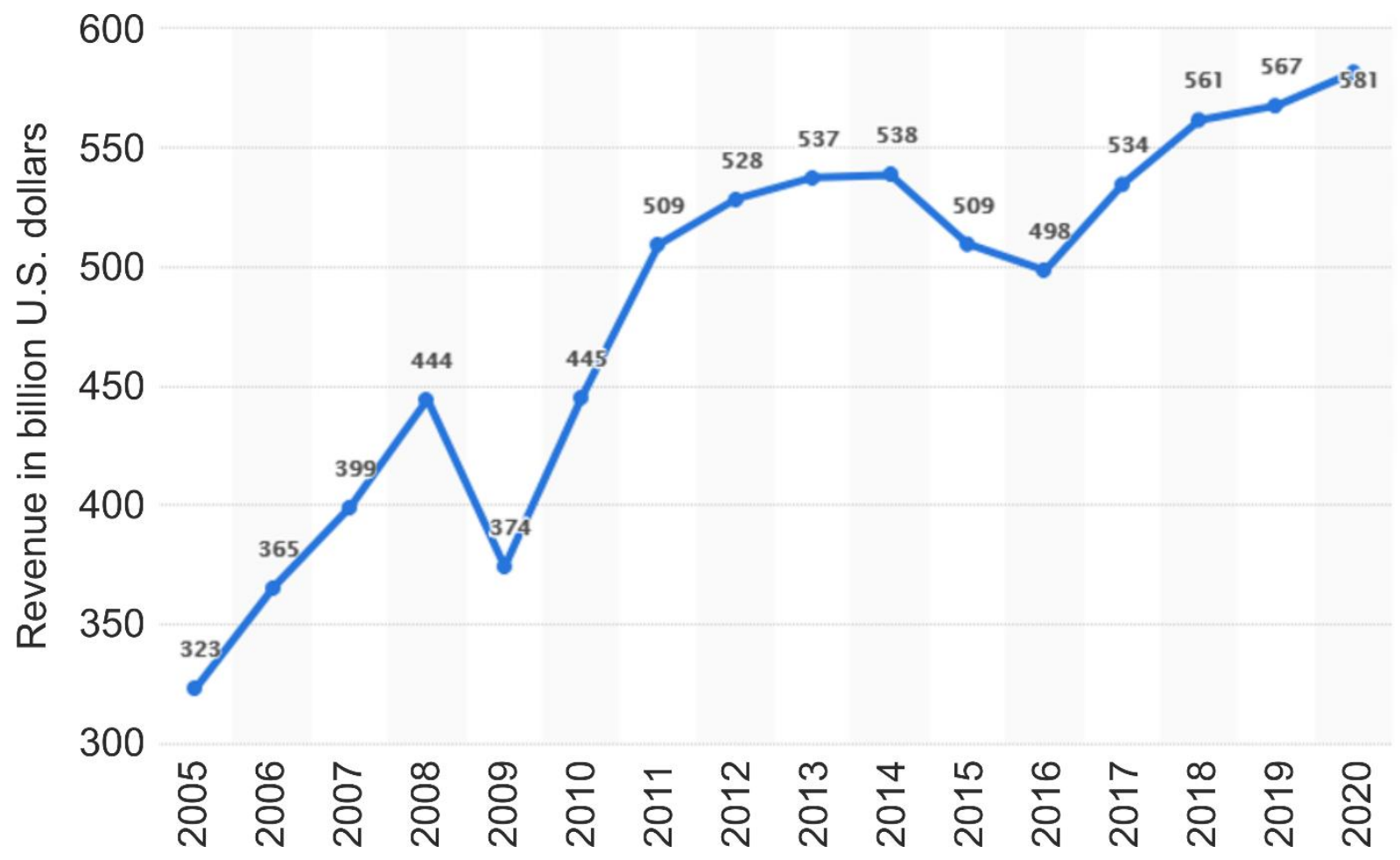

Figure 2. The Worldwide Revenue with Passengers in Air Traffic in Billions of U.S. dollars (2005 -2020)

Source: Statista (2020).

In the agreement with (OAG, 2020), Europe has seen the most extensive contraction of air services of any world region in the period of March-May 2020. While the European countries, including the United Kingdom, France, Ireland, Spain and Italy, are in the process of easing their lockdown conditions, there is a lot of caution and air travel, especially international air travel, continues to be widely restricted. The last week of May 2020, the number of scheduled flights operating was down by $68 \%$ compared to the same week of 2019 . Furthermore, a lot of countries continue to maintain restrictions on arrivals of air travelers, and also in many markets appear to have stabilized frequency reductions (OAG, 2020). Additionally, India, which was supposed to come out of lockdown in the last week of May, extended the lockdown for another fortnight, and this means that air industry will continue to be affected. 


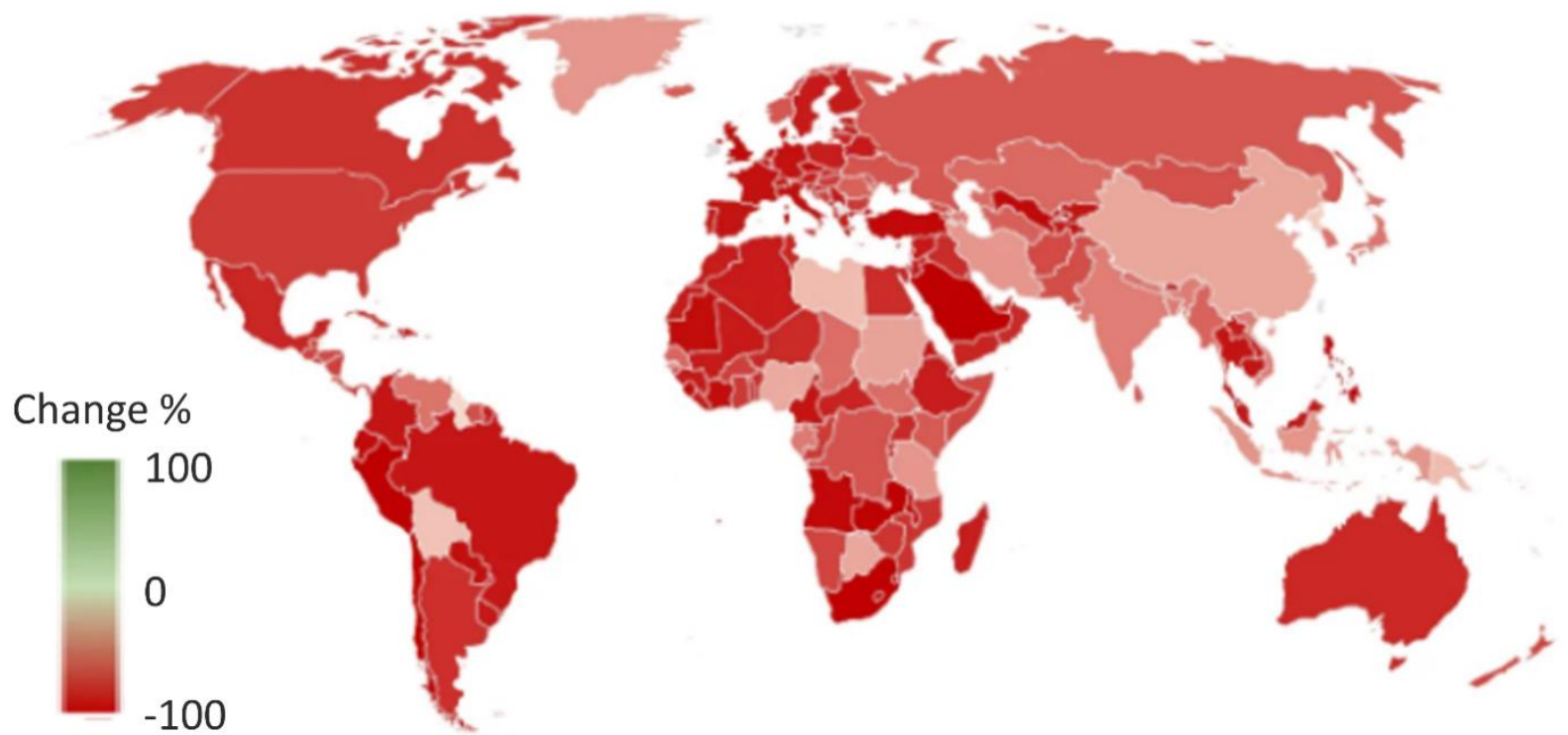

Figure 3. The Worldwide Change in Flights Compared to 2019 (the Week of 25th May 2020) Source: OAG (2020).

Table 1. The Global Scheduled Flights Change in January-May 2020

\begin{tabular}{ccccccccc}
\hline Countries & January & February & March & April & May 4 & May 11 & May 18 & May 25 \\
\hline ALL & $0.8 \%$ & $-8.6 \%$ & $-14.8 \%$ & $-64.5 \%$ & $-69.9 \%$ & $-68.4 \%$ & $-67.6 \%$ & $-68.6 \%$ \\
\hline Spain & $-3.7 \%$ & $-1.8 \%$ & $-23.2 \%$ & $-94.0 \%$ & $-92.3 \%$ & $-92.1 \%$ & $-94.4 \%$ & $-94.5 \%$ \\
\hline Hong Kong & $-9.7 \%$ & $-46.5 \%$ & $-77.6 \%$ & $-93.5 \%$ & $-93.6 \%$ & $-89.7 \%$ & $-89.3 \%$ & $-89.1 \%$ \\
\hline Germany & $-8.5 \%$ & $-6.9 \%$ & $-30.7 \%$ & $-92.9 \%$ & $-90.5 \%$ & $-91.2 \%$ & $-91.4 \%$ & $-92.1 \%$ \\
\hline Singapore & $-0.1 \%$ & $-16.1 \%$ & $-43.1 \%$ & $-93.8 \%$ & $-97.0 \%$ & $-96.9 \%$ & $-95.7 \%$ & $-96.7 \%$ \\
\hline Italy & $-3.3 \%$ & $-4.2 \%$ & $-48.0 \%$ & $-85.6 \%$ & $-78.1 \%$ & $-78.3 \%$ & $-84.2 \%$ & $-92.4 \%$ \\
\hline France & $-0.8 \%$ & $0.4 \%$ & $-15.3 \%$ & $-90.6 \%$ & $-91.9 \%$ & $-91.1 \%$ & $-91.9 \%$ & $-92.1 \%$ \\
\hline The UK & $-3.8 \%$ & $-3.3 \%$ & $-22.8 \%$ & $-92.3 \%$ & $-92.5 \%$ & $-92.3 \%$ & $-93.9 \%$ & $-94.6 \%$ \\
\hline Australia & $-3.5 \%$ & $-3.2 \%$ & $-5.7 \%$ & $-82.6 \%$ & $-83.0 \%$ & $-83.6 \%$ & $-84.0 \%$ & $-82.2 \%$ \\
\hline Sweden & $-9.2 \%$ & $-5.6 \%$ & $-22.7 \%$ & $-87.0 \%$ & $-88.5 \%$ & $-88.5 \%$ & $-89.4 \%$ & $-87.9 \%$ \\
\hline The UAE & $-1.9 \%$ & $-3.0 \%$ & $-23.1 \%$ & $-81.1 \%$ & $-78.1 \%$ & $-77.4 \%$ & $-78.8 \%$ & $-82.0 \%$ \\
\hline South Korea & $2.2 \%$ & $-11.6 \%$ & $-49.5 \%$ & $-56.7 \%$ & $-49.5 \%$ & $-50.7 \%$ & $-49.1 \%$ & $-48.7 \%$ \\
\hline The USA & $1.7 \%$ & $1.2 \%$ & $-2.2 \%$ & $-56.9 \%$ & $-74.5 \%$ & $-74.7 \%$ & $-73.5 \%$ & $-73.9 \%$ \\
\hline India & $2.1 \%$ & $6.3 \%$ & $7.6 \%$ & $-83.3 \%$ & $-90.9 \%$ & $-66.8 \%$ & $-24.6 \%$ & $-44.9 \%$ \\
\hline China & $4.3 \%$ & $-55.1 \%$ & $-40.2 \%$ & $-42.6 \%$ & $-32.0 \%$ & $-27.4 \%$ & $-28.8 \%$ & $-27.0 \%$ \\
\hline Japan & $2.4 \%$ & $-3.5 \%$ & $-16.5 \%$ & $-40.3 \%$ & $-47.0 \%$ & $-47.9 \%$ & $-44.9 \%$ & $-48.8 \%$ \\
\hline SOurce: OAG 2020$)$ & & & & & & &
\end{tabular}

Source: OAG (2020). 

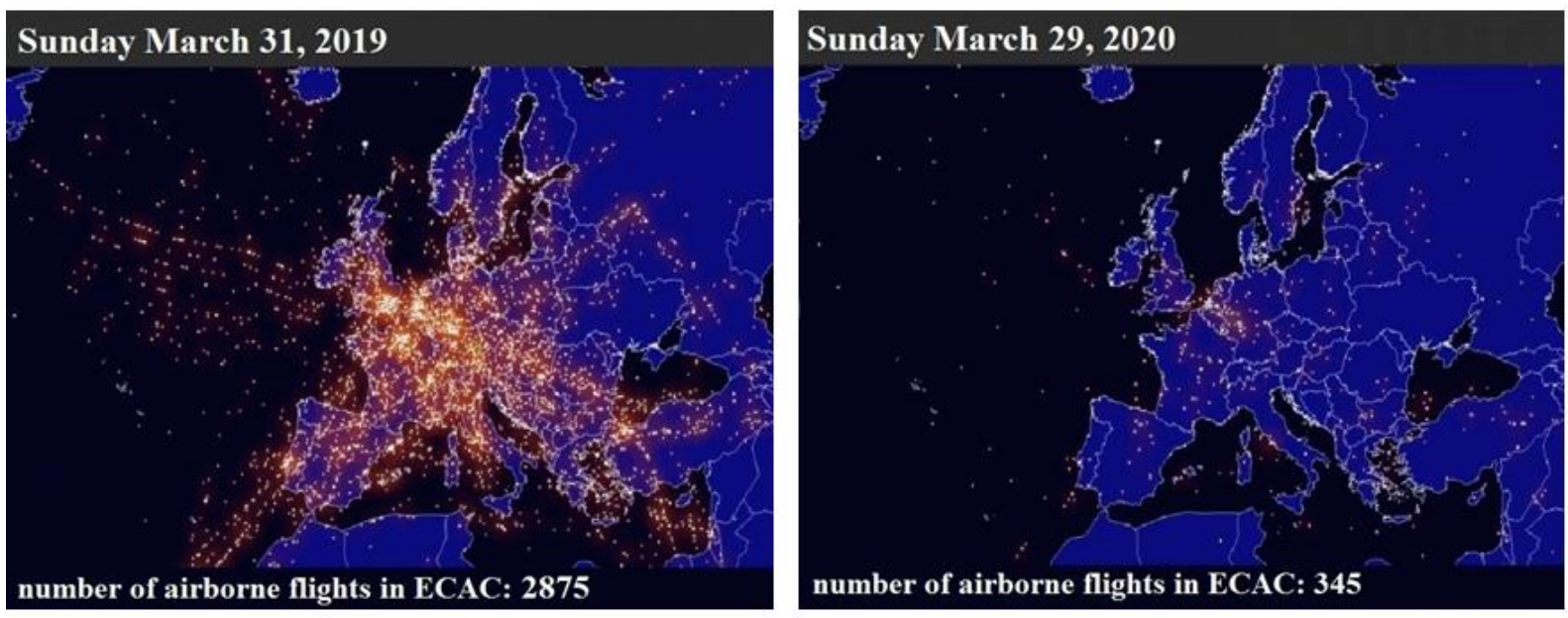

Figure 4. A Comparison that Shows the Dramatic Impact of the Coronavirus Lockdown on the Flights across the European Airspace. The data published by Eurocontrol (2020) shows there was a fall of $88 \%$ on flights compared with 2019.

Source: Eurocontrol (2020).

The main conclusion that could be drawn is that the novel coronavirus's rapid spread globally is forcing the aviation industry and air transport to survive in uncertainty. Mass cancellations of flights around the world produced devastating financial losses. The situation is classified as an 'extraordinary circumstance' and it is beyond the air companies' control.

\section{Predictions for the Future of Tourism in the Post-Coronavirus Era}

A recent report suggests that self-isolation could lead to an increase in consumers' searching their future holidays. A survey found that $55 \%$ of the US consumers, who usually travel five or more times per year, say they may or will likely purchase a future holiday while confined to their homes during the COVID-19 outbreak, while for frequent business travelers, this figure rises to $61 \%$ (Econsultancy, 2020). On the other hand, as specified by the managing director of Hospitality and Tourism International Consulting (HTI Consulting), a possible timeline is between one and two years for the hospitality industry across Africa and the Middle East to reach pre-coronavirus levels (Travel Daily News, 2020).

As long as the planet confronts the realities of the worldwide pandemic, there is an opportunity to rethink what tourism will look like for the decades ahead (Brouder, 2020). As hospitality, travel and tourism industries work to recover from the coronavirus crisis, stakeholders' decisions must be grounded on creditable scientific authentication. It is also significant to remember that COVID-19 is not the first disaster of its kind to strike the tourism industry, as in 2003 SARS brought similar effects (Wen et al., 2020). A come-back to prepandemic growth patterns requires time and depends on the depth and extent of the recession sparked by the novel coronavirus (Prideaux, 2020). 
As businesses catalyze outstandingly both in helping society get through a financial crisis and in creating innovations that shape the society after an emergency, there arises a principal issue: how will the current crisis modify the future society? While it seems hard to predict the future, it is more feasible to develop understanding of what is ahead by analyzing current trends. There have already been observed considerable changes in business practices (Delaporte \& Pena, 2020), and the new global norm is to work from home (Dingel \& Neiman, 2020; Gallacher \& Hossain, 2020).

As maintained by VivekWadhwa (Foreign Policy, 2020) it is very possible that the next leap forward will come from the virtual reality, which is advancing at a breakneck speed. Activities such as family vacations, business meetings, and leisure activities will increasingly move into the virtual world. In the past decades, e-Tourism, as an area of scientific research, has evolved into a sizeable body of knowledge with the focus on theory and information technology development oriented towards the core issues in tourism (Gretzel et al., 2020).

In short, it can be argued that the coronavirus has accelerated technology trends almost in all the human activities. During the pandemic, technologies are playing an important role as they keep the society functional in times of quarantines and lockdowns. Technological applications such as virtual reality could be significantly useful for promotion strategies of travel destinations after the travel restrictions period.

\section{Hotels' New Policies in Crisis Times}

The hospitality industry is facing an existential crisis, because of the coronavirus spread and the global lockdown. This pandemic creates panic among the public, which contributes to a decrement trend in the tourism industry (Bakar \& Rosbi, 2020). As the coronavirus pandemic spreads around the world, many hotels are starting to advertise quarantine packages to guests (Folinas\& Metaxas, 2020). Lockdown (Bakar \& Roshbi, 2020, Sheresheva, 2020) as an extended practice adopted by a number of countries around the world produces the need to self-isolate for a lot of people. So, several hotels earn money by offering their rooms to people who want to self-isolate due to the spread of the pandemic (Folinas \& Metaxas, 2020).

Although this situation makes tourism highly vulnerable, the sector is also in a unique position to contribute to broader and just recovery plans and actions. All over the world, tourism represents development opportunities, promotes solidarity and understanding beyond borders, while domestic tourism also helps to foster cohesion within nations (DUNC, 2020). Chains and boutique hotels alike are offering quarantine packages for those interested in selfisolation (Boutique Hotel News, 2020). Thailand's 'A-One' Hotel group is one of the first to offer a self-isolation package within its doors. Bangkok and Pattaya hotels offer full board packages to Thais or other residents seeking to isolate in their hotels, with the various towels, linens and other essential services handled separately by special staff. Rates for these packages have been slashed by $20 \%$ as the hotel hopes to gain traffic during an industry wide downturn (Chang et al., 2020; Lapointe, 2020). With few people traveling right now, Thailand's A-One Hotels Group is employing a new tactic to attract bookings by offering a self-quarantine 
package at its Bangkok and Pattaya hotels. These full-board packages are targeted at Thais or residents who wish to isolate themselves for 14 days. Meals are delivered to the rooms on trolleys, while dishes, cutlery and bed sheets used by guests in self-isolation will be separated for special handling. A special team will provide daily housekeeping services and help monitor the conditions of the guests under quarantine. Should any of these guests become unwell or develop any coronavirus symptoms during their stay at the hotel, they will be immediately sent to the several hospitals located in the hotel's vicinity, according to the company's director. These packages are priced very competitively with rates slashed by $20 \%$ (Skift, 2020). This risky strategy is a first reaction to the challenge that faces the global hospitality industry (The Wall Street Journal, 2020). This policy seems to be followed by other hotel industry companies around the world; the Dorsett chain of hotels, for example, is selling a two-week or 27-day quarantine package at nine locations, according to the Wall Street Journal. Guests must have their temperatures checked twice a day to see if they're exhibiting symptoms of the virus, which include fever. They can order meals through online food delivery services or through the hotel's concierge.

Some of Hong Kong's high-end hotels are offering similar packages as well. The Park Lane Hong Kong has a 14-day package that runs for $\$ 2,525$ and includes three meals a day. In Singapore, some hotels are offering reduced rates to people who need to quarantine. The Fairmont Singapore has a two-week package with a daily rate of about half the hotel's usual rate (The Real Deal, 2020). At the same time, Asset World Corp has announced the temporary closure of five hotels in Bangkok from March 26 to April 15 to reduce the risk of spreading the Covid19 disease. The five hotels closed are: Bangkok Marriott Marquis Queen's Park Hotel, DoubleTree by Hilton Sukhumvit Bangkok Hotel, Le Meridien Bangkok Hotel, The Okura Prestige Hotel Bangkok and the Bangkok Marriott Hotel the Surawongse (Skift, 2020).

In Australia, the Novotel Sydney Brighton Beach (2020), a resort-style 4.5-star hotel, which belongs to Accor Hotels Group, is offering an extended stay discount of $40 \%$ off the best available rate for bookings of 14 nights or more. The promotion comes with several perks, including a complimentary room upgrade, an all-inclusive room service package and complimentary Wi-Fi \& parking (The Points Gay News, 2020). According to the hotel, selfisolating guests will be provided with fresh linens and amenities on request, delivered to their door, and left outside for collection, and also common areas of the hotel are frequently and thoroughly cleaned and disinfected to the most stringent standards, paying special attention to high touch-point areas.

In Switzerland, the 'Bijou Hotel \& Resort' made up of repurposed luxury apartments, advertises them as "quarantine apartments" on its COVID-19 service page. Furthermore, this hotel invites all healthcare workers fighting the coronavirus and need a break to stay at 'Le Bijou' free of charge (Le Bijou, 2020). This strategy could bring future benefits to the company, as the literature shows that relationship marketing, focused on transactional tactics, such as trips and holiday gifts, is possible to be a major instrument for hospitality enterprise development (Khan \& McCleary, 1996; Kim et al., 2001; Bowen \& Shoemaker, 2003). 
In South Africa, the National Coronavirus Command Council has announced risk-adjusted strategy regulations effective from March 27, 2020. All domestic and international travel remains prohibited as well as interprovincial movement but in exceptional circumstances. All hotels and establishments remain closed. The only exception is about accommodating international tourists who remain in South Africa, or providing accommodation for essential services people (Official COVID-19 Recourse Centre for South African Tourism, 2020). The only chance to stay open for the hotels in South Africa is to be appointed as quarantine facilities. These accommodations establishments must be approved by the Department of Health as appropriate. In Greece, as well, despite the governmental decision ordering the temporary closure of the country's hotels, those establishments which could offer accommodation to medical and healthcare personnel, armed forces, the EU officials, foreign students, impacted individuals, education staff, asylum seekers or refuges, were excluded from the ban. The Hellenic Chamber of Hotels chose fifty among those that expressed interest (Greek City Times, 2020).

Thus, summarizing the above, it can be noted that even in very difficult times of travel restrictions and almost no tourism activity, some hospitality companies exploit the potential of the current situation adapting to a changing business environment, create and provide new packages for the new kinds of clients.

\section{Conclusions}

One of the vulnerabilities of the tourism industry is that it is built entirely around a discretionary commodity: the travel. Travel restrictions are often the first action suggested as the most effectual way to diminish the spread of a transmittable disease or pandemic in cases of health emergencies. In consequence, in the case of COVID-19 outbreak, the official rules and governmental restrictions that limit the worldwide travel, have brought catastrophic effects on the global tourism industry.

In conclusion, the coronavirus has paralyzed the worldwide economic system. The global GTP growth was infected highly due to the almost general lockdown of the planet. Airlines industry already feels the catastrophic effects of its diachronic enemy - the economic recession. Tourism industry, which depends exceedingly on transport and mobility, may be considered as the 'great patient of the pandemic'. Tens of millions of employees have already faced or are facing losing jobs, and as reflected, the coronavirus-induced crisis will cast a long shadow over the hospitality sector.

But even in these critical times, with upcoming crises in the fragile sector of tourism, some hotels succeed to drum up business, from the potential tourists' current needs, and they promote new products like self-quarantine packages. Thus 'quarantined guests' are a new type of hotel clients but only for the big hospitality companies which have the possibility to provide premium isolation with daily health-care monitoring. Tour operators and hospitality sector stakeholders have to be specialized in smaller groups' host. Furthermore, hospitality managers and tourism sector practitioners must take steps to set up crisis management plans 
which must provide survival strategies such as reduction of costs, virtualization, orderliness, domestication and integration. A lot of indicators show that global tourism activity is heading towards a change of paradigm, a new framework that is yet to be discovered, explored, and adapted.

\section{Acknowledgements}

I address my sincere thanks to Marie-Noëlle Duquenne, a professor of 'statistical and econometric methods for spatial analysis' at the University of Thessaly, for her patience, availability and all her wise advice, which have fueled my reflection, S.F.

\section{Formatting of Funding Sources}

The authors declare that they haven't received any funding to support their research.

\section{Disclosure Statement}

No potential conflict of interest was reported by the authors.

\section{References}

Albulescu, C. (2020). Coronavirus and Oil Price Crash. Retrieved from https://papers.ssrn.com/sol3/papers.cfm?abstract_id=3553452

Arghyrou, M., \& Kontonikas, A. (2012). The EMU Sovereign-Debt Crisis: Fundamentals, Expectations and Contagion, Journal of International Financial Markets. Institutions and Money, 22(4), 658-77. http://dx.doi.org/10.1016/j.intfin.2012.03.003

Aydın, B., \& Doğan, M. (2020). Evaluation of Effects of the COVID-19 Pandemic on Touristic Consumption Behavior and Tourism in Turkey. Journal of Theory and Practice in Marketing, 6(1), 93-115.

Ayittei, F., Ayittei, M., Chiwero, N., Kamasah, J., \& Dzuvor, C. (2020). Economic Impacts of Wuhan 2019nCoV ON China and the World. Journal of Medical Virology, 92, 473-75, http://dx.doi.org/10.1002/jmv.25706

Aznar, J.P., Sayeras, J.M, Rocafort, A., \& Galiana, J. (2017). The Irruption of Airbnb and its Effects on Hotel Profitability: An Analysis of Barcelona's Hotel Sector. Intangible Capital, 13(1), 147-59. http://dx.doi.org/10.3926/ic.921

Bakar, N.A., \& Rosbi, S. (2020). Effect of Coronavirus Disease (COVID-19) to Tourism Industry, International Journal of Advanced Engineering Research and Science, 7(4), 189-193. https://dx.doi.org/10.22161/ijaers.74.23

Bannò, M., \& Redondi, R. (2014). Air Connectivity and Foreign Direct Investments: Economic Effects of the Introduction of New Routes. European Transport Research Review, 6(4), 355-63. https://dx.doi.org/10.1007/s12544-014-0136-2 
Barro, R., Ursua, J., \& Weng, J. (2020). The Coronavirus and the Great Influenza Epidemic - Lessons from the "Spanish Flu" for the Coronavirus's Potential Effects on Mortality and Economic Activity, CESifo Working Paper, No. 8166. Munich: Center for Economic Studies and Ifo Institute. Retrieved from https://www.econstor.eu/bitstream/10419/216562/1/cesifo1_wp8166.pdf

Beirne, J., \& Fratzscher, M. (2013). The Pricing of Sovereign Risk and Contagion during the European Sovereign Debt Crisis. Journal of International Money \& Finance, 34, 60-82. https://doi.org/10.1016/j.jimonfin.2012.11.004

Bossomaier, T., Barnett, L., Steen, A., Harre, M., d'Alessandro, S., \& Duncan, R. (2018). Information Flow about Stock Market Collapse. Accounting \& Finance, 58, 45-58. https://doi.org/10.1111/acfi.12390

Boutique Hotel News. (2020). Global Hotels Providing Quarantine Packages for Self-Isolating Travelers. Retrieved from https://www.boutiquehotelnews.com/news/industry/global-hotelsprovidingquarantine-packages-for-self-isolating-travellers

Bowen, J., \& Shoemaker, S. (2003). Loyalty: A Strategic Commitment. The Cornell Hotel and Restaurant Administration Quarterly, 44(5-6), 31-46. https://doi.org/10.1177/001088049803900104

Brouder, P. (2020). Reset Redux: Possible Evolutionary Pathways towards the Transformation of Tourism in a COVID-19 World. Tourism Geographies International Journal of Tourism Space, Place and Environment. https://doi.org/10.1080/14616688.2020.1760928

Business Insider. (2020a). Coronavirus Demolishes Air Travel around the World. Retrieved from https://www.businessinsider.com/air-traffic-during-coronavirus-pandemic-changes-effects-arou nd-the-world-2020-4

Business Insider. (2020b). Some of the World's Airlines Could Go Bankrupt because of the COVID-19 Crisis, According to an Aviation Consultancy. Retrieved from https://www.businessinsider.com/coronavirus-airlines-that-failed-bankrupt-covid19-pandemic2020-3

Carlsson-Szlezak, P., Reeves, M., \& Swartz, P. (2020). What Coronavirus Could Mean for the Global Economy. Harvard Business Review. Retrieved from: http://zums.ac.ir/files/i_management/files/24.pdf

Cboe. (2020). VIX Index Historical Data. Retrieved from http://www.cboe.com/products/vix-indexvolatility/vix-options-and-futures/vix-index/vix- historical-data

Chang, C.-L., McAleer, M., \& Ramos, V. (2020). A Charter for Sustainable Tourism after COVID-19. Sustainability, 12, 3671. https://doi.org/10.3390/su12093671

Chava, S., \& Purnanandam, A. (2012). The Effect of Banking Crisis on Bank-Dependent Borrowers. Journal of Financial Economics, 99(1), 116-35. https://doi.org/10.1016/j.jfineco.2010.08.006

Chinazzi, M., Davis, J., Ajelli, M., Gioannini, C., Litvinova, M., Merler, S., Pastore y Piontti, A., Mu, K., Rossi, L., Sun, K., Viboud, C., Xiong, X., Yu, H., Halloran, E., LonginiJr, I., \& Vespignani, A. (2020). The Effects of Travel Restrictions on the Spread of the 2019 Novel Coronavirus (COVID-19) Outbreak. Science, 368(6489), 395-400. http://doi.org/10.1126/science.aba9757

Condé Nast Traveller. (2020). Coronavirus Air Travel: These Numbers Show the Massive Impact of the Pandemic. Retrieved from https://www.cntraveler.com/story/coronavirus-air-travel-thesenumbers-show-the-massive-impact-of-the-pandemic 
Correa-Martínez, C., Kampmeier, S., Kümpers, P., Schwierzeck, V., Hennies, M., Hafezi, W., Kühn, J., Pavenstädt, H., Ludwig, S., \& Mellmanna, A. (2020). A Pandemic in Times of Global Tourism: Superspreading and Exportation of COVID-19 Cases from a Ski Area in Austria. Journal of Clinical Microbiology, 58(6), e00588-20, http://doi.org/10.1128/JCM.00588-20

Delaporte, I., \& Pena, W. (2020). Working from Home Under COVID-19: Who Is Affected? Evidence from Latin American and Caribbean Countries. CEPR COVID Economics, 14. Retrieved from https://ssrn.com/abstract=3610885

Dingel, J.I., \& Neiman, B. (2020). How Many Jobs Can Be Done at Home? CEPR Discussion Paper No. DP14584. Retrieved from https://ssrn.com/abstract=3594206

Domínguez-Mujica, J., González-Pérez, J., \& Parreño-Castellano, J. (2011). Tourism and Human Mobility in Spanish Archipelagos. Annals of Tourism Research, 38(2), 586-606. https://doi.org/10.1016/j.annals.2010.11.016

DUNC. (2020). COVID-19: Challenges and Opportunities for the Tourism Sector and How DUNC is Coping with the Current Situation. Retrieved from https://www.dunc-heritage.eu/covid-19-challengesand-opportunities-for-the-tourism-sector-and-how-dunc-is-coping-with-the-current-situation/

Dungey, M., Fry, R., González-Hermosillo, B., \& Martin, V. (2006). Contagion in International Bond Markets during the Russian and the LTCM Crises. Journal of Financial Stability, 2(1), 1-27. https://doi.org/10.1016/j.jfs.2005.01.001

Econsultancy. (2020). How Travel and Tourism Brands are Reacting to Coronavirus. Retrieved from https://econsultancy.com/how-travel-tourism-brands-reacting-coronavirus-social-media/

Englund, P. (1999). The Swedish Banking Crisis: Roots and Consequences. Oxford Review of Economic Policy, 15(3), 80-97. https://doi.org/10.1093/oxrep/15.3.80

Eric, T.N., Semeyutin, A., \& Hubbard, N. (2020). Kenyan Tourism Industry and Their Likely Welfare Implications. Tourism Management, 78. https://doi.org/10.1016/j.tourman.2019.104033

Estrada, M., Park, D., \& Lee, M. (2020). How a Massive Contagious Infectious Diseases Can Affect Tourism, International Trade, Air Transportation, and Electricity Consumption? The Case of 2019 Novel Coronavirus (2019-nCoV) in China (February 19, 2020). Retrieved from https://papers.ssrn.com/sol3/papers.cfm?abstract_id=3540667

Eurocontrol. (2020). COVID-19 Impact on the European Air Traffic Network. Retrieved from https: //www.eurocontrol.int/covid19

European Investment Bank. (2020). Does This Change Everything? Air Travel and Coronavirus. Retrieved from https://www.eib.org/en/stories/coronavirus-impact-air-travel

Fernandes, N. (2020). Economic Effects of Coronavirus Outbreak (COVID-19) on the World Economy. Retrieved from https://papers.ssrn.com/sol3/papers.cfm?abstract_id=3557504

Folinas, S., \& Metaxas, T. (2020). Tourism: The Great Patient of Coronavirus COVID-19. International Journal of Advanced Research, 8(5), 365-75. http://dx.doi.org/10.21474/IJAR01/10788

Foreign Policy. (2020). The Future of Travel after the Coronavirus Pandemic. Retrieved from https:// foreignpolicy.com/2020/06/13/travel-tourism-coronavirus-pandemic-future/

Gabrielli, L., Deutschmann, E., Natale, F., Recchi, E., \& Vespe, M. (2019). Dissecting Global Air Traffic Data to Discern Different Types and Trends of Transnational Human Mobility. EPJ Data Science, 8(1), 1-24. https://doi.org/10.1140/epjds/s13688-019-0204-x 
Gallacher, G., \& Hossain, I. (2020). Remote Work and Employment Dynamics under Covid-19: Evidence from Canada. Canadian Public Policy/Analyse de politiques. [pre-publication version]. Retrieved from https://www.utpjournals.press/doi/pdf/10.3138/cpp.2020-026

Goodnight, T., \& Green, S. (2010). Rhetoric, Risk, and Markets: The Dot-Com Bubble. Quarterly Journal of Speech, 96(2), 115-40. https://doi.org/10.1080/00335631003796669

Gössling, S., Scott, D., \& Hall, C.M. (2020). Pandemics, Tourism and Global Change: a Rapid Assessment of COVID-19. Journal of Sustainable Tourism. https://doi.org/10.1080/09669582.2020.1758708

Greek City Times. (2020). List of Hotels in Greece that Will Remain Open during the Coronavirus Pandemic. Retrieved from https://greekcitytimes.com/2020/03/24/list-of-hotels-in-greece-thatwill-remain-open-during-the-coronavirus-pandemic/

Gretzel, U., Fuchs, M., Baggio, R., Hoepken, W., Law, R., Neidhardt, J., Pesonen, J., Zanker, M., \& Xiang, Z. (2020). E-Tourism beyond COVID-19: A Call for Transformative Research. Information Technology \& Tourism, 22, 187-203. https://doi.org/10.1007/s40558-020-00181-3

Hall, C.M., Scott, D., \& Gössling, S. (2020.) Pandemics, Transformations and Tourism: Be Careful What You Wish for. Tourism Geographies. https://doi.org/10.1080/14616688.2020.1759131

Hasanat, M.W., Hoque, A., Shikha, F.A., Anwar, M., Abdul-Hamid, A.B., \& Tat, H. (2020). The Impact of Coronavirus (Covid-19) on E-Business in Malaysia. Asian Journal of Multidisciplinary Studies, 3(1), $1-6$.

Hoque, A., Shikha, F.A., Hasanat, M.W., Arif, I., \& Abdul-Hamid, A.B. (2020). The Effect of Coronavirus (COVID-19) in the Tourism Industry in China. Asian Journal of Multidisciplinary Studies, 3(1), 1-7.

Jorion, P. (2000). Risk Management Lessons from Long-Term Capital Management, European Financial Management, 6(3), 277-300. https://doi.org/10.1111/1468-036X.00125

lacus, S., Natale, F., Santamaria, C., Spyratos, S., \& Vespe, M. (2020). Estimating and Projecting Air Passenger Traffic during the COVID-19 Coronavirus Outbreak and its Socio-Economic Impact. Safety Science, 128. https://doi.org/10.1016/j.ssci.2020.104791

Ivy, R.L., Fik, T.J., \& Malecki, E.J. (1995). Changes in Air Service Connectivity and Employment, Environment and Planning, 27(2), 165-79. https://doi.org/10.1068/a270165

Kabir, H., \& Hassan, K. (2005). The Near-Collapse of LTCM, US Financial Stock Returns, and the Fed, Journal of Banking \& Finance, 29(2), 441-60. https://doi.org/10.1016/j.jbankfin.2004.05.014

Khan, M., \& McCleary, K. (1996). A Proposed Model for Teaching Ethics in Hospitality. Hospitality and Tourism Educator, 8(4), 7-12. https://doi.org/10.1080/23298758.1996.10685751

Kim, K., Baek, C., \& Lee, J.D. (2018). Creative Destruction of the Sharing Economy in Action: The Case of Uber. Transportation Research Part A: Policy and Practice, 110, 118-27. https://doi.org/10.1016/j.tra.2018.01.014

Kim, W.G., Han, J.S., \& Lee, E. (2001). Effects of Relationship Marketing on Repeat Purchase and Word of Mouth. Journal of Hospitality and Tourism Research, 25(3), 72-88, https://doi.org/10.1177/109634800102500303

Kumar, S. (2020). Impact of Coronavirus (COVID-19) on Indian Economy. Agriculture \& Food, 2(4), 301302.

Lamsfus, C., Martín, D., Alzua-Sorzabal, A., \& Torres-Manzanera, E. (2015). Smart Tourism Destinations: An Extended Conception of Smart Cities Focusing on Human Mobility. In I. Tussyadiah \& A. Inversini 
(Eds.), Information and Communication Technologies in Tourism 2015. Cham: Springer. https://doi.org/10.1007/978-3-319-14343-9_27

Lane, P. (2012). The European Sovereign Debt Crisis. Journal of Economic Perspectives, 26(3), 49-68. http://doi.org/10.1257/jep.26.3.49

Lapointe, D. (2020). Reconnecting Tourism after COVID-19: the Paradox of Alterity in Tourism Areas. Tourism Geographies, 22(3). http://doi.org/10.1080/14616688.2020.1762115

Le Bijou. (2020). Hotel Service, without the Other Hotel Guests. Retrieved from https://lebijou.com/

Lew, A. (2011). Tourism's Role in the Global Economy. Tourism Geographies, 13(1), 148-51. https://doi.org/10.1080/14616688.2010.531046

Maffioli, E. (2020). How is the World Responding to the Novel Coronavirus Disease (COVID-19) Compared with the 2014 West African Ebola Epidemic? The Importance of China as a Player in the Global Economy. The American Journal of Tropical Medicine and Hygiene, 102(5), 924-925. https://doi.org/10.4269/ajtmh.20-0135

Metaxas, T., \& Folinas, S. (2016). Gambling Tourism and Economic Development: Some Lessons from Macao. Munich Personal RePEc Archive, Unpublished. Retrieved from https://mpra.ub.unimuenchen.de/72397/

Mishkin, F.S. (1992). Anatomy of a Financial Crisis. Journal of Evolutionary Economics, 2, 115-130, https://doi.org/10.1007/BF01193536

Niewiadomski, P. (2020). COVID-19: from Temporary De-Globalisation to a Rediscovery of Tourism?. Tourism Geographies. https://doi.org/10.1080/14616688.2020.1757749

Novotel Sydney Brighton Beach. (2020). Self-isolate by the Bay. Retrieved from https://www.novotelbrightonbeach.com.au/en/special-offers/self-isolate-package.html

OAG. (2020). Coronavirus: Understanding the Airline Schedule Changes and Manage the Impact. Retrieved from: https://www.oag.com/coronavirus-airline-schedules-data

Official COVID-19 Recourse Centre for South African Tourism. (2020). Risk Adjusted National Lockdown. Retrieved from https://www.southafrica.net/gl/en/trade/page/coronavirus-covid-19-southafrican-tourism-update

Oskam, J., \& Boswijk, A. (2016). Airbnb: the Future of Networked Hospitality Businesses. Journal of Tourism Futures, 2(1), 22-42. https://doi.org/10.1108/JTF-11-2015-0048

Prideaux, B. (2020). Lessons from COVID-19 Can Prepare Global Tourism for the Economic Transformation Needed to Combat Climate Change. Tourism Geographies. https://doi.org/10.1080/14616688.2020.1762117

Recchi, E., Deutschmann, E., \& Vespe, M. (2019). Estimating Transnational Human Mobility on a Global Scale. Schuman Centre for Advanced Studies. Research Paper, 30, 1-10. Retrieved from https://cadmus.eui.eu/bitstream/handle/1814/62326/RSCAS_2019_30.pdf?sequence=1

Şenol, Z., \& Zeren, F. (2020). Coronavirus (COVID-19) and Stock Markets: The Effects of the Pandemic on the Global Economy, Eurasian Journal of Research in Social and Economics, 7(4), 1-16.

Sheresheva, M.Y. (2020). Coronavirus and Tourism. Population and Economics, 4(2), 72-76. https://doi.org/10.3897/popecon.4.e53574 
Skift. (2020). Coronavirus and the Travel Industry. Retrieved from https://skift.com/coronavirus-andtravel/

Statista. (2020). Worldwide Revenue with Passengers in Air Traffic from 2005 to 2020 in Billion U.S. Dollars. Retrieved from https://www.statista.com/statistics/263042/worldwide-revenue-withpassengers-in-air-traffic/

The Points Gay News. (2020). Need to Self-Isolate? These Hotels are Offering Quarantine Packages. Retrieved from https://thepointsguy.com/news/hotel-quarantine-packages-coronavirus/

The Real Deal. (2020). Coming to a Hotel Near You: The $\$ 2,500$ Coronavirus Quarantine Package. Retrieved from https://therealdeal.com/2020/03/19/coming-to-a-hotel-near-you-the-2500coronavirus -quarantine-package/

The Wall Street Journal. (2020). Do Not Disturb: Hotels Hammered by Coronavirus Offer 14-Day Quarantine Packages. Retrieved from https://www.wsj.com/articles/hit-by-coronavirusslowdown-hotels-try-catering-to-the-quarantined-11584624502

Travel Daily News. (2020). Covid-19 Impact Could be Huge Opportunity for Value-Driven Tourism Products Like Aparthotels'. Retrieved from https://www.traveldailynews.com/post/ covid-19impact-could-be-huge-opportunity-for-value-driven-tourism-products-like-aparthotels

Van Houts, D. (1984). Air Transport and International Tourism: An Examination of the Distribution of the Benefits between Developed and Developing Countries. Tourist Review, 39(1), 16-18. https://doi.org/10.1108/eb057894

Wen, J., Wang, W., Kozak, M., Liu, X., \& Hou, H. (2020). Many Brains are Better Than One: the Importance of Interdisciplinary Studies on COVID-19 in and beyond Tourism. Tourism Recreation Research. https://doi.org/10.1080/02508281.2020.1761120

WorldAware. (2020). COVID-19 Prompts Concerns of Social and Political Instability in Middle East and North Africa. Retrieved from https://www.worldaware.com/resources/blog/covid-19-pro mpts-concerns-social-and-political-instability-middle-east-and-north

Yang, Y., Zhang, H., \& Chen, X. (2020). Coronavirus Pandemic and Tourism: Dynamic Stochastic General Equilibrium Modeling of Infectious Disease Outbreak. Annals of Tourism Research, [Epub ahead of print]. https://doi.org/10.1016/j.annals.2020.102913

Yozcu, O.K., \& Cetin, G. (2019). A Strategic Approach to Managing Risk and Crisis at Tourist Destinations. In N. Kozak \& M. Kozak (Eds.), Tourist Destination Management (pp. 273-287). Cham: Springer. https://doi.org/10.1007/978-3-030-16981-7_16 